\title{
ULOGA OSOBNIH ČIMBENIKA U OBJAŠNJENJU KOMPULZIVNOG PREJEDANJA
}

\author{
DANIJELA BOŽIĆ, IVANA MACUKA \\ Odjel za psihologiju Sveučilišta u Zadru, kontakt: danijelabozic13@gmail.com, ivana.moranduzzo@unizd.hr
}

Primljeno: 12.04.2017.

Prihvaćeno: 14.06.2017.
Izvorni znanstveni rad

UDK: 616.89-008.441.42

Sažetak: Kod različitih oblika poremećaja hranjenja zajedničko obilježje je pretjerani utjecaj tjelesnog izgleda i težine u samoevaluaciji pojedinca uz neredovite ili kaotične obrasce unosa hrane. Zaseban poremećaj hranjenja kompulzivno prejedanje uključuje unos neuobičajeno velike količine hrane u kratkom vremenskom razdoblju kojeg prati intenzivan osjećaj gubitka kontrole. Dosadašnja istraživanja ukazuju na važnu ulogu raznih osobnih čimbenika u objašnjenju sklonosti kompulzivnom prejedanju, a cilj ovog istraživanja bio je ispitati zasebnu ulogu sposobnosti emocionalne regulacije i kontrole, razine uzbuđenja uslijed negativnog raspoloženja, samokritičnosti i samoohrabrivanja te indeksa tjelesne mase u objašnjenju sklonosti kompulzivnog prejedanja. U istraživanju su sudjelovale 302 djevojke prosječne dobi 22 godine $(S D=2,70)$, a podaci su prikupljeni online upitnikom. Hijerarhijskom regresijskom analizom utvrđeni su zasebni doprinosi pojedinih skupina osobnih čimbenika objašnjenju kompulzivnog prejedanja kod djevojaka. Značajne samostalne odrednice kompulzivnog prejedanja su razina uzbuđenja uslijed negativnog raspoloženja i razina nevoljenog selfa kao zasebna dimenzija samokritičnosti. Zaključno, dobiveni rezultati ukazuju kako su djevojke s višom razinom uzbuđenja uslijed negativnog raspoloženja i višom razinom nevoljenog selfa sklonije kompulzivnom prejedanju, a odabrane osobne varijable u ovom istraživanju ukupno objašnjavaju 45,6\% varijance kompulzivnog prejedanja.

Ključne riječi: kompulzivno prejedanje, emocionalna regulacija, uzbuđenje uslijed negativnog raspoloženja, samokritičnost, samoohrabrivanje, indeks tjelesne mase

\section{UVOD}

Prehrana ima važnu ulogu u tjelesnom zdravlju pojedinca, a problemi i poremećaji s prehranom snažno negativno utječu ne samo na tjelesno zdravlje, već i na svakodnevno emocionalno i socijalno funkcioniranje osobe. Općenito se danas velika pažnja posvećuje tjelesnom izgledu te ideal ženske ljepote podrazumijeva vitkost koja graniči s mršavošću, a takvi ideali su osobito nametani od strane medija i modne industrije. Istovremeno danas bilježimo i porast stope pretilosti u zemljama u razvoju kao posljedicu sjedilačkog načina života, manje tjelesne aktivnosti i prehrane bogate industrijski prerađenim namirnicama. Pretjerano naglašavanje vitkosti kao i negativno stereotipiziranje pretilih osoba može rezultirati osjećajem izrazitog nezadovoljstva vlastitim tjelesnim izgledom te posljedično može dovesti do pogrešnih stavova prema hranjenju, pretjerane zabrinutosti tjelesnom težinom i čestim držanjem dijete koja naposljetku može uzrokovati specifične poremećaje hranjenja (Lake i sur., 2000).
Poremećaji hranjenja se općenito definiraju kao samoinicijativno izgladnjivanje ili prejedanje (Fairburn, 1995) uz istaknutu zabrinutost slikom vlastitog tijela, općenito nezadovoljstvom tjelesnim izgledom, usmjerenošću na kontrolu težine i izgleda te neprilagođenim obrascima unošenja hrane (Pokrajac-Bulian, 2000). U etiologiji zasebnih poremećaja hranjenja (anoreksije, bulimije, kompulzivnog prejedanja) ističu se različiti osobni i okolinski čimbenici čime se naglašava kompleksnost uzroka navedenih poremećaja. I dok se u prijašnjim istraživanjima više isticala uloga bioloških čimbenika (kao što su spol, dob i tjelesna težina), danas se više naglašava uloga psiholoških (perfekcionizam, samopoštovanje, zadovoljstvo tijelom i emocionalna regulacija) i socijalnih čimbenika (utjecaj vršnjaka, roditelja i medija). Općenito zajedničko obilježje različitih oblika poremećaja hranjenja je pretjerani utjecaj oblika tijela i tjelesne težine na samoevaluaciju te neredoviti ili kaotični obrasci unosa hrane. I dok se pažnja istraživača prije više usmjeravala na poremećaje prehrane ano- 
reksiju i bulimiju, u novije vrijeme se veća pažnja pridaje kompulzivnom prejedanju kao zasebnom poremećaju hranjenja, ali i kao obrascu ponašanja koji se pojavljuje iz različitih razloga, te ne mora imati značajke poremećaja (Peck i Lightsey, 2008).

\section{Definicija i prevalencija kompulzivnog prejedanja}

Kompulzivno prejedanje (eng. binge eating) ozbiljan je i iscrpljujući problem koji podrazumijeva unos neuobičajeno velike količine hrane $u$ kratkom vremenskom razdoblju uz osjećaj gubitka kontrole (Pokrajac-Bulian i sur., 2009). U DSMIV (DSM-IV; American Psychiatric Association, 1994), kompulzivno prejedanje nije bilo prepoznato kao zaseban poremećaj hranjenja, dok je u DSM-V (DSM-V; American Psychiatric Association 2013) kompulzivno prejedanje uvršteno kao zaseban poremećaj hranjenja (uz anoreksiju i bulimiju) te uključuje ponavljajuće epizode prejedanja pri čemu osobe u kratkom vremenskom razdoblju (manjem od 2 sata) unose količinu hrane koja je zamjetno veća od količine koju bi većina ljudi pojela tijekom sličnog vremenskog perioda i tijekom sličnih okolnosti. Ujedno je u ovom poremećaju istaknut i osjećaj gubitka kontrole tijekom trajanja epizode prejedanja, odnosno osoba osjeća da ne može prestati jesti ili kontrolirati koliko jede. Prevalencijski podaci ukazuju da se poremećaj kompulzivnog prejedanja javlja kod $3.5 \%$ žena i $2 \%$ muškaraca (Hudson i sur., 2007). Prema DSM-V (APA, 2013), dvanaestomjesečna prevalencija poremećaja kompulzivnog prejedanja, kod odraslih ljudi iz SAD-a (18-godišnjaci i stariji) za žene iznosi $1.6 \%$, a za muškarce $0.8 \%$. Prema Goldschmidtu i suradnicima (2015) prejedanje se javlja kod 5-10\% adolescenata, što čini poremećaj prejedanja najčešćim u toj dobnoj skupini. Muškarci i žene koji pate od poremećaja kompulzivnog prejedanja pate često i od pretilosti te istraživanja upućuju da preko $30 \%$ pretilih osoba pati od poremećaja kompulzivnog prejedanja (Hood i sur., 2013; Prisco i sur., 2013). U općoj populaciji $8 \%$ prekomjerno teških žena zadovoljava kriterije kompulzivnog prejedanja (Ambrosi-Randić, 2004), a stope kompulzivnog prejedanja su posebno visoke među studenticama s prevalencijom od $32 \%$ (Keel i sur., 2007) do $48 \%$ (Striegel-Moore i sur., 1990).

\section{Rodne i dobne razlike u kompulzivnom prejedanju}

Žene općenito češće pate od poremećaja hranjenja (Kelly-Weeder i sur., 2012), sklonije su jesti više nego inače od muškaraca u stresnim situacijama (Mouchacca i sur., 2013), te češće jedu između obroka od muškaraca (O Connor i sur., 2008). Baum i Contrada (2011) upućuju da su žene sklonije kompulzivnom prejedanju u situacijama suočavanja sa stresnim životnim situacijama i negativnim emocijama (osobito ljutnjom i anksioznosti). Danas su i muškarci sve više izloženi medijskim pritiscima vezanim uz dijete i mišićava tijela, što je dovelo do dramatičnog porasta poremećaja hranjenja i kod muškaraca (Strother i sur., 2012). Neka istraživanja sugeriraju kako ne postoji značajna razlika između muškaraca i žena u sklonosti kompulzivnom prejedanju (Striegel-Moore i Franko, 2003; Grucza i sur., 2007), dok druga istraživanja pokazuju veću prevalenciju kompulzivnog prejedanja kod žena (Hudson i sur., 2007; Preti i sur., 2009). Prosječna dob početka kompulzivnog prejedanja jest kasna adolescencija ili rane dvadesete godine (Fairburn, 1995), a prosječno trajanje poremećaja je 8 godina (Hudson i sur., 2007). Prejedanje ne mora nužno biti patološko stanje, te se može pojaviti zbog stresa (Polivy i sur., 2005) ili kao pokušaj kontroliranja negativnih emocija (Vancampfort i sur., 2013). Ono što se smatra ključnim u razlikovanju prejedanja kao poremećaja hranjenja od prejedanja kao obrasca hranjenja jest osjećaj gubitka kontrole (Keel i Levit, 2006). Osjećaj gubitka kontrole kod prejedanja je povezan sa značajnim problemima, pogoršanjima i problematičnim obrascima hranjenja, kako u transverzalnim (Goldschmidt i sur., 2008, Shomaker i sur., 2010) tako i u longitudinalnim istraživanjima (Goldschmidt, i sur., 2011; Hilbert i sur., 2009). Kompulzivno prejedanje je ozbiljan problem, te u odsutnosti liječenja može napredovati u ozbiljan poremećaj hranjenja (Stice i Whitenton, 2002), dok prejedanje kao obrazac hranjenja može nakon nekog vremena i prestati. Istraživanja ukazuju kako ipak određeni postotak adolescenata koji su izvještavali o kompulzivnom prejedanju u adolescenciji, navodi da su s takvim ponašanjem nastavili i nekoliko godina kasnije (Goldschmidt i sur., 2014). 


\section{Etiologija kompulzivnog prejedanja - teorijski pristupi}

U pokušajima pojašnjenja uzroka nastanka i održavanja kompulzivnog prejedanja postoji nekoliko teorija: teorija izbjegavanja (Heatheron i Baumeister, 1991), teorija ograničavanja unosa hrane (teorija suzdržavanja) (Polivy i sur., 2005), model afektivne regulacije (Johnoson i Larson, 1982) te kognitivno - bihevioralni model (Fairburn, 2008). Najobuhvatnije objašnjenje nudi teorija izbjegavanja u okviru koje je istaknuto kako je kompulzivno prejedanje isključivo posljedica motivacije da se izbjegne averzivna ili negativna svijest o sebi (Heatherton i Baumeister, 1991). Odnosno, pojedinci koji imaju izrazito negativno mišljenje o sebi su usmjereni na vlastite nedostatke, slabosti i neuspjehe te se procjenjuju prema visoko postavljenim standardima i nedostižnim idealima (Pokrajac-Bulian i sur., 2009). Upravo je uspoređivanje s visoko postavljenim standardima glavna komponenta perfekcionizma, a istraživanja potvrđuju važan doprinos ove osobine u poremećajima hranjenja (Soares i sur., 2009). Također osobe sklone kompulzivnom prejedanju često imaju uvjerenje da drugi ljudi obraćaju pažnju i kritiziraju njihovo ponašanje (Etu i Gray, 2010), općenito su nezadovoljne sobom, a svijest o vlastitim nedostatcima rezultira češćim neugodnim raspoloženjima koja se nastoje izbjeći unošenjem velike količine hrane. Osobe koje pokazuju visoku razinu svijesti o sebi se procjenjuju u skladu s vrlo zahtjevnim kriterijima i često ne udovoljavaju svojim očekivanjima. Stoga usmjeravanjem na neke druge podražaje (primjerice na hranu), rješavaju ili ublažavaju neugodna emocionalna stanja. Nadalje, prema teoriji ograničavanja unosa hrane, osobe svjesno ograničavaju količinu hrane kako bi kontrolirale tjelesnu težinu, ali su u stresnim situacijama koje narušavaju njihovo dijetno ponašanje sklonije kompulzivnom prejedanju (Polivy i sur., 2005). Dodatno pojašnjenje ovih obrazaca problema i poremećaja u hranjenju nam nudi i model afektivne regulacije prema kojem se kompulzivno prejedanje javlja zbog pokušaja reguliranja emocija, odnosno kao odgovor na stres ili ostala neugodna emocionalna stanja (Johnson i Larson, 1982). Kompulzivno prejedanje u takvim situacijama pruža udobnost, distrakciju i/ili olakšanje od averzivnih afektivnih stanja (Cooper i sur., 2005; Heatheron i Baumiester, 1991; Fox i Power, 2009; Spoor i sur., 2007; Del Parigi i sur., 2003). Prema kognitivno-bihevioralnom modelu Fairburn (2008) opisuje prejedanje kao disfunkcionalan način reguliranja raspoloženja koje služi kao način ublažavanja neugodnog raspoloženja tako da interferira s kognicijama koje su odgovorne za neugodna emocionalna stanja.

Kao što je već istaknuto, istraživanja uzroka poremećaja kompulzivnog prejedanja predstavljaju razmjerno novu i neistraženu temu, osobito u Hrvatskoj. Stoga se u okviru ovog istraživanja nastojalo obuhvatiti neke osobne čimbenike koji mogu imati važnu ulogu u objašnjenju sklonosti kompulzivnom prejedanju. Među ključnim odrednicama kompulzivnog prejedanja zasigurno treba istaknuti sposobnost regulacije i kontrole emocija koja je istaknuta u okviru prethodno navedenog modela afektivne regulacije. Emocije imaju važnu ponašajnu i kognitivnu komponentu te se pojavljuju u različitim situacijama koje pojedinac procjenjuje važnima, ali postoje i situacije u kojima se emocije pojave u krivo vrijeme ili u pogrešnom intenzitetu. Sposobnost kontrole emocija, odnosno proces kojim osoba utječe na to koju će emociju iskazati, kao i kada i na koji način se opisuje pojmom emocionalne regulacije (Gross, 1998). Emocionalna regulacija se općenito odnosi na sposobnost odgovaranja na stresne zahtjeve $i$ emocionalna iskustva na adaptivan način (Cole $i$ sur., 2004; Morris i sur., 2007), te omogućava osobi da se zaštititi od neugodnih emocija i obuzda na način da ne ometaju njeno svakodnevno funkcioniranje (Gross, 2001). Poteškoće u emocionalnoj regulaciji i kontroli mogu dovesti do poremećaja hranjenja u čijoj je osnovi nedostatak adekvatnih strategija reguliranja negativnih emocionalnih stanja. Primjerice, kod poremećaja kompulzivnog prejedanja, prejedanje služi kao distraktor, odnosno pažnja se s negativnih emocija prebacuje na hranu kako bi se doživio osjećaj kratkotrajnog zadovoljstva (Svaldi i sur., 2010). Istraživanja potvrđuju navedeni odnos kompulzivnog prejedanja i neadaptivnog reguliranja negativnih emocija (OrzolekKronner, 2002; Gianini i sur., 2013; Brockmeyer i sur., 2014; Gilboa-Schechtman i sur., 2006).

Osobine ličnosti su važni etiološki čimbenici kompulzivnog prejedanja te većina pojedinaca 
oboljelih od poremećaja hranjenja iskazuje visoku razinu negativne emocionalnosti (neuroticizma) $i$ impulzivnosti (Claes i sur., 2005; Lilenfeld i sur., 2006). Međutim impulzivnost je široki konstrukt koji obuhvaća više dimenzija kao što je nedostatak planiranja i/ili traženje uzbuđenja (Whiteside i Lynam, 2009), a u objašnjenju kompulzivnog prejedanja nije jasno upuštaju li se pojedinci u kompulzivno prejedanje zbog izrazite potrebe za stimulacijom, zbog izbjegavanja negativnih emocija ili jednostavno zato što ne uzimaju u obzir dugoročne posljedice svog kompulzivnog ponašanja. Neka istraživanja dokazuju kako i impulzivnost i uzbuđenje uslijed negativnog raspoloženja imaju važnu ulogu u objašnjenju kompulzivnog prejedanja (Anestis i sur., 2009; Claes i sur., 2005). Specifično, uzbuđenje uslijed negativnog raspoloženja predstavlja tendenciju pojedinca da se ponaša naglo ili impulzivno prilikom doživljavanja negativnih emocija. Drugim riječima, pojedinci koji su više skloni uzbuđenju uslijed negativnog raspoloženja ujedno su i skloniji izgubiti kontrolu nad svojim ponašanjem u situacijama kada se osjećaju neraspoloženo ili tužno (Cyders i Smith, 2007; Claes i sur., 2005), odnosno iskazuju impulzivna ponašanja kao način suočavanja s negativnim emocijama (Smith i Tran, 2007). Istraživanja potvrđuju značajan doprinos traženja uzbuđenja uslijed negativnog raspoloženja u objašnjenju povećane razine kompulzivnog prejedanja kod žena u većini longitudinalnih (Fischer i sur., 2013; Pearson i sur., 2012) i transverzalnih istraživanja (Carrard i sur., 2012; Kelly i sur., 2013).

Među odrednicama kompulzivnog prejedanja važno je istaknuti i ulogu samokritičnosti koja se odnosi na samoevaluacijski proces u kojem osoba proučava i osuđuje različite aspekte sebe, kao što su osobine ličnosti, tjelesni izgled i ponašanje (Shahar i sur., 2015). Samokritični pojedinci konstantno sagledavaju i promišljaju o vlastitim greškama i lošim atributima (primjerice vezane uz vlastiti tjelesni izgled). Također, samokritičnost se odnosi na stil odgovaranja na percipirane neuspjehe koji su karakterizirani osuđivanjem i negativnom samoevaluacijom (Gilbert i sur., 2004). Iako se većina osoba u svakodnevnim situacijama samoevaluira, ljudi koji doživljavaju visoke razine samokritičnosti, poprimaju oštra prijezirna ponašanja usmjerena upravo prema sebi. Tako se napad na sebe aktivira kada ljudi osjećaju da su pogriješili u nekim važnim aspektima svoga života ili kada stvari krenu neočekivanim smjerom $u$ životu. Samokritični pojedinci pri tome iskazuju intenzivan osjećaj mržnje, odbojnosti i prijezira usmjerenih prema sebi, a upravo takve emocije su česte kod osoba koje se samoozljeđuju (Gilbert i sur., 2004). Gilbert i suradnici (2004) navode različite dimenzije samokritičnosti koje obuhvaćaju način kako se ljudi ponašaju prema sebi u situacijama neuspjeha i gubitka osobnog ili socijalnog statusa, a to su neadekvatan self i nevoljeni self. Neadekvatan self se odnosi na osjećaje vlastite neadekvatnosti u određenim situacijama, dok se nevoljeni self odnosi na osjećaje gađenja i mržnje prema sebi sa željom samoozljeđivanja i samoranjavanja. Takav oblik samokritičnosti pokazao se posebno povezanim sa psihološkom patnjom te osobe koje imaju višu razinu nevoljenog selfa češće iskazuju poremećaje osobnosti i psihotične poremećaje (Birchwood i sur., 2000; Castilho i sur., 2015). Zasebni samoohrabrujući self se odnosi na ohrabrivanje i podržavanje samog sebe u negativnim životnim situacijama i događajima. U nizu istraživanja ukazano je da je samokritičnost prediktor psihopatoloških simptoma, posebno depresivnosti i anksioznosti (Dunkley i sur., 2003, Gilbert i sur., 2004; Gilbert i sur., 2006), samoozljeđivanja (Gilbert i sur., 2014), i poremećaja hranjenja (Kupeli i sur., 2012). S druge strane, samoohrabrivanje je povezano s većom psihološkom dobrobiti (Gilbert i sur., 2004; 2006). Rezultati nekih istraživanja (Dunkley i Grilo, 2007) podržavaju značajnu povezanost samokritičnosti i poremećaja hranjenja, osobito kompulzivnog prejedanja. Unatoč činjenici da negativne samoevaluacije doprinose razvoju poremećaja hranjenja, veza između samokritičnosti i kompulzivnog prejedanja kao poremećaja hranjenja još uvijek nije dovoljno istražena, te dobiva iznenađujuće malo empirijske pažnje.

Indeks tjelesne mase je najčešća metoda za procjenu stanja uhranjenosti i procjene učestalosti pothranjenosti i pretilosti unutar populacije (Colditz, i sur., 1995). On je ujedno jedan od mogućih objektivnih pokazatelja poremećaja hranjenja jer pomaže u određivanju je li je neka osoba po svojoj težini prosječna, više ili manje ispod ili pak iznad pro- 
sječne težine. Indeks tjelesne mase (ITM=kg/m²) ispod 18 ukazuje na ozbiljnu neuhranjenost osobe i prijetnje za njeno tjelesno zdravlje. Indeks tjelesne mase jednak i preko 25 znači da je osoba prekomjerno teška, dok indeks tjelesne mase jednak i preko 30 znači da je osoba pretila. Međutim, vrlo je važno razlikovati pretilost od poremećaja kompulzivnog prejedanja. Iako zbog unosa velike količine kalorija osobe s poremećajem kompulzivnog prejedanja često imaju prekomjernu tjelesnu težinu, sve osobe koje su pretile nemaju poremećaj kompulzivnog prejedanja. Postoje određene nekonzistentnosti u istraživanjima odnosa indeksa tjelesne mase i kompulzivnog prejedanja. Primjerice, rezultati istraživanja Mackenzie i Harrisa (2015) upućuju kako se pojedinci s povišenim indeksom tjelesne mase i oni s normalnim indeksom ne razlikuju u sklonosti kompulzivnom prejedanju. S druge strane, rezultati drugih istraživanja upućuju kako je većina pretilih osoba sklona učestalom kompulzivnom prejedanju (Bulik i Reichborn-Kjennerud, 2003; Hudson i sur., 2007).

\section{Cilj, problemi i hipoteze istraživanja}

Cilj ovog istraživanja je bio ispitati relativan zaseban doprinos sposobnosti emocionalne regulacije i kontrole neugodnih emocija, razine uzbuđenja uslijed negativnog raspoloženja, dimenzija samokritičnosti (neadekvatan i nevoljeni self), samoohrabrivanja te indeksa tjelesne mase u objašnjenju sklonosti kompulzivnog prejedanja. Odabir ispitanih osobnih čimbenika je izvršen na temelju uvodno prikazanih istraživanja i teorijskih razmatranja o mogućim uzrocima kompulzivnog prejedanja. Postojeća razmatranja ove problematike ukazuju da se može očekivati kako će viša razine emocionalne regulacije i kontrole neugodnih emocija te samoohrabrivanje biti značajni negativni prediktori kompulzivnog prejedanja, dok će razina uzbuđenja uslijed negativnog raspoloženja te neadekvatan self i nevoljeni self kao dimenzije samokritičnosti biti značajni pozitivni prediktori kompulzivnog prejedanja. S druge strane, budući na nekonzistentnost doprinosa indeksa tjelesne mase $\mathrm{u}$ istraživanjima kompulzivnog prejedanja ne mogu se postaviti jednoznačne hipoteze o njegovom doprinosu objašnjenju kompulzivnog prejedanja.

\section{METODA}

\section{Sudionici istraživanja}

Istraživanje je provedeno na prigodnom uzorku od 342 sudionika, odnosno 302 djevojke te 40 mladića. S obzirom na mali broj mladića $(\mathrm{N}=40)$ koji su pristali sudjelovati u istraživanju, te znatnim nepotpunim ispunjavanjem pojedinih upitnika, odlučeno je kako će se daljnje obrade podataka provesti samo na ženskom dijelu sudionika, odnosno na ukupno 302 sudionice u dobi od 18 do 29 godina, prosječne dobi 22 godine $(M=22,64$, $\mathrm{SD}=2,70$ ). Indeks tjelesne mase (ITM) izračunat je preko formule iz podataka o težini i visini sudioni$\mathrm{ka}\left(\mathrm{ITM}=\mathrm{kg} / \mathrm{m}^{2}\right)$ te se kretao u rasponu od 15 do 40, dok je prosječan indeks tjelesne mase iznosio $23(\mathrm{M}=23,23, \mathrm{SD}=4,92)$ te ukazuje kako sudionice ovog istraživanja imaju većinom normalnu tjelesnu težinu. Njihova prosječna tjelesna visina je 1,69 metara $(\mathrm{M}=1,69, \mathrm{SD}=0,07)$, a prosječna težina $66,18 \mathrm{~kg}(\mathrm{M}=66,18, \mathrm{SD}=12,29)$.

\section{Postupak provedbe istraživanja}

Istraživanje je provedeno tijekom ožujka, travnja i svibnja 2016. godine primjenom online upitnika koji je kreiran pomoću web aplikacije Google Docs. Upitnik je objavljen na različitim Facebook grupama kako bi se prikupili podatci na području cijele Hrvatske. Upitniku je prethodila uputa u kojoj su sudionici zamoljeni da upitnike ispunjavaju iskreno i potpuno te je naglašeno kako je sudjelovanje $u$ istraživanju dobrovoljno i anonimno te da će se podatci koristiti isključivo $u$ istraživačke svrhe.

\section{Mjerni instrumenti}

Ljestvica prejedanja (Binge Eating Scale, Gormally, Black, Daston i Rardin, 1982; adaptirana hrvatska verzija Pokrajac-Bulian, Tkalčić i Ambrosi - Randić, 2013)

Ljestvica prejedanja se sastoji od 16 tvrdnji namijenjenih mjerenju sklonosti kompulzivnom prejedanju. Ispituje se učestalost, trajanje i opis epizode prejedanja kao i averzivne emocije prisutne za vrijeme i nakon prejedanja. Za svaku tvrdnju sudionik odabire jedan od tri ili četiri moguća odgovora koji ukazuju na sklonost prejedanju: 1)"Ne osjećam 
krivnju niti se mrzim nakon što previše pojedem.“; 2) „Ponekad osjećam krivnju ili se mrzim nakon što previše pojedem.";3)"Gotovo uvijek doživljavam snažnu krivnju ili se mrzim nakon što previše pojedem." Ukupan rezultat se formira kao prosječna vrijednost procjena na svim tvrdnjama te se kreće od 0 do 46, pri čemu rezultat manji od 17 ukazuje na nepostojanje rizika za poremećaj prejedanja, rezultat od 18 do 26 ukazuje na blagi do umjereni poremećaj prejedanja, dok rezultat viši od 27 ukazuje na ozbiljan poremećaj. U ovom istraživanju je potvrđena jednofaktorska struktura skale uz visoku pouzdanost unutarnje konzistencije od 0,91.

Upitnik samokritičnosti i samoohrabrivanja (The Forms of Self-Criticising/Attacking \& Self Reassuring Scale (FSCRS), Gilbert, Clarke, Hempel, Miles i Irons, 2004; adaptirana hrvatska verzija Božić, 2017)

Upitnik samokritičnosti i samoohrabrivanja je skala namijenjena mjerenju samokritičnosti i sposobnosti samoohrabrivanja. Sastoji se od 22 čestice raspoređenih u 3 subskale, dvije subskale se odnose na samokritičnost: neadekvatan self (eng. inadequate self) koji se usmjerava na osjećaj osobne neadekvatnosti (,Lako se razočaram u sebe") $\mathrm{i}$ nevoljeni self (eng. hated self), koji mjeri želju za ranjavanjem ili mučenjem sebe (,Postanem toliko ljut na sebe da se želim ozlijediti"), a treća subskala se odnosi na samoohrabrivanje, tj. na ohrabrujući self (eng. reassure self) (,Lako mi je voljeti samu sebe"). Odgovori se daju na skali procjene od 5 stupnjeva (od 0 do 4) (0 - uopće se ne odnosi na mene do 4 - u potpunosti se odnosi na mene). Ukupan rezultat računa se kao prosjek procjena na tvrdnjama pojedinih subskala, pri čemu viši rezultat ukazuje na višu razinu samokritičnosti (kod subskala neadekvatnog i nevoljenog selfa), dok kod subskale ohrabrujućeg selfa, viši rezultat ukazuje na višu razinu ohrabrivanja i podržavanja samog sebe. Upitnik ima zadovoljavajuću pouzdanost uz koeficijent unutrašnje konzistencije od 0,92 za neadekvatan self, 0,87 za nevoljeni i 0,89 za ohrabrujući self.

Skala uzbuđenja uslijed negativnog raspoloženja (Negative Urgency Scale, Lynam, Smith, Whiteside i Cyders, 2006; adaptirana hrvatska verzija Božić, 2017)
Skala uzbuđenja uslijed negativnog raspoloženja (negative urgency) se sastoji od 12 tvrdnji kojima se ispituje sklonost osobe traženju uzbuđenja uslijed negativnog raspoloženja (,Imam poteškoća s odupiranjem mojim žudnjama (za hranom, ciga-

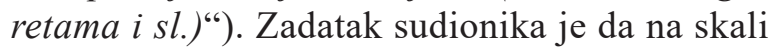
procjene od 1 do $4(1-u$ potpunosti se ne slažem do 4 - u potpunosti se slažem) procjeni vlastito slaganje s navedenom tvrdnjom. Ukupan rezultat se formira kao prosječna vrijednost procjena na svim tvrdnjama i kreće se u rasponu od 12 do 48. Viši rezultat ukazuju na veću sklonost traženja uzbuđenja uslijed negativnog raspoloženja. Korištena skala u ovom istraživanju ima zadovoljavajuću pouzdanost uz koeficijent unutrašnje konzistencije od 0,89 .

\section{Upitnik emocionalne regulacije i kontrole (ERIK; Takšić, 2003)}

Upitnik emocionalne regulacije i kontrole procjenjuje učinak neugodnih emocija i raspoloženja na mišljenje, pamćenje i ponašanje pojedinca. Upitnik se sastoji od 20 tvrdnji kojima je cilj procjena negativnih efekata emocija i raspoloženja na mišljenje, pamćenje, kao i sposobnost emocionalne kontrole (,Kada me netko naljuti, odmah $i$ vrlo burno reagiram"). Zadatak sudionika je da na skali procjene od 5 stupnjeva (od 1- uopće ne do 5 - u potpunosti) procijene koliko se pojedina tvrdnja odnosi na njih. Kako bi se lakše interpretirali rezultati, tvrdnje koje se odnose na emocionalnu regulaciju i kontrolu u ovom su se istraživanju obrnuto bodovale, te se viši rezultat odnosi na bolje upravljanje i bolju kontrolu negativnih emocija. Korišten upitnik ima zadovoljavajuću pouzdanost uz koeficijent unutrašnje konzistencije od 0,92.

\section{REZULTATI}

\section{Deskriptivni pokazatelji i povezanosti mjerenih varijabli}

Prije analiza provedenih u svrhu odgovora na postavljen problem istraživanja, prikazana je tablica deskriptivnih parametara varijabli ispitivanih $\mathrm{u}$ istraživanju i bivarijatnih korelacija među svim mjerenim varijablama $(\mathrm{N}=302)$. S obzirom da je normalna distribucija rezultata osnovan uvjet za primjenu parametrijskih analiza, prikazani su i 
Tablica 1. Deskriptivni parametri $i$ interkorelacije ispitivanih varijabli $(N=302)$

\begin{tabular}{|c|c|c|c|c|c|c|c|}
\hline & \begin{tabular}{|c|}
$\begin{array}{c}\text { Kompulzivno } \\
\text { prejedanje }\end{array}$ \\
\end{tabular} & $\begin{array}{c}\text { Emocionalna } \\
\text { regulacija i } \\
\text { kontrola }\end{array}$ & \begin{tabular}{|c} 
Uzbuđenje \\
uslijed \\
negativnog \\
raspoloženja
\end{tabular} & $\begin{array}{c}\text { Neadekvatan } \\
\text { Self }\end{array}$ & $\begin{array}{l}\text { Nevoljeni } \\
\text { Self }\end{array}$ & $\begin{array}{l}\text { Ohrabrujući } \\
\text { Self }\end{array}$ & $\begin{array}{c}\text { Indeks } \\
\text { tjelesne mase }\end{array}$ \\
\hline $\begin{array}{l}\text { Kompulzivno } \\
\text { Prejedanje }\end{array}$ & - & $-0,45^{* *}$ & $0,52 * *$ & $0,55 * *$ & $0,63 * *$ & $-0,46^{* *}$ & 0,03 \\
\hline $\begin{array}{l}\text { Emocionalna } \\
\text { regulacija } \\
\text { i kontrola }\end{array}$ & & - & $-0,72 * *$ & $-0,64 * *$ & $-0,56^{* *}$ & $0,38 * *$ & $-0,06$ \\
\hline $\begin{array}{l}\text { Uzbuđenje } \\
\text { uslijed } \\
\text { negativnog } \\
\text { raspoloženja }\end{array}$ & & & - & $0,58 * *$ & $0,54 * *$ & $-0,42^{* *}$ & $-0,01$ \\
\hline Neadekvatan self & & & & - & $0,75^{* *}$ & $-0,52 * *$ & 0,02 \\
\hline $\begin{array}{l}\text { Nevoljeni } \\
\text { Self }\end{array}$ & & & & & - & $-0,58 * *$ & 0,06 \\
\hline Ohrabrujući self & & & & & & - & 0,08 \\
\hline $\begin{array}{l}\text { Indeks } \\
\text { tjelesne } \\
\text { mase }\end{array}$ & & & & & & & - \\
\hline $\begin{array}{l}\text { Aritmetička } \\
\text { Sredina }\end{array}$ & 14,37 & 2,91 & 2,41 & 1,87 & 0,85 & 2,74 & 23,23 \\
\hline $\begin{array}{l}\text { Standardna } \\
\text { Devijacija }\end{array}$ & 8,37 & 0,75 & 0,66 & 0,98 & 1,01 & 0,80 & 4,92 \\
\hline Minimum & 0 & 1 & 1 & 0 & 0 & 0 & 15,07 \\
\hline Maximum & 46 & 5 & 4 & 4 & 4 & 4 & 40,40 \\
\hline $\begin{array}{l}\text { Kolmogorov- } \\
\text { Smirnov test }\end{array}$ & $0,10^{*}$ & 0,05 & 0,06 & 0,07 & $0,21^{*}$ & $0,10^{*}$ & 0,07 \\
\hline $\begin{array}{l}\text { Indeks } \\
\text { asimetričnosti }\end{array}$ & 0,86 & 0,26 & $-0,00$ & 0,07 & 1,17 & $-0,68$ & 0,82 \\
\hline $\begin{array}{l}\text { Indeks } \\
\text { spljoštenosti }\end{array}$ & 0,43 & 0,28 & $-0,83$ & $-0,91$ & 0,22 & 0,10 & 0,89 \\
\hline
\end{tabular}

Napomena: $*<0,01 ; * *<0,001$

rezultati Kolmogorov-Smirnovljevog (K-S) testa normaliteta distribucije, te indeksi spljoštenosti i asimetričnosti.

Kako bi se provjerio oblik distribucije rezultata, korišten je Kolmogorov-Smirnovljev test koji se za pojedine varijable kreće u rasponu od 0,05 do 0,21. Za kompulzivno prejedanje je ustanovljeno kako distribucija rezultata statistički značajno odstupa od normalne s tendencijom grupiranja rezultata oko nižih vrijednosti. Iz Tablice 1 vidljivo je da i rezultati nevoljenog i ohrabrujućeg selfa pokazuju asimetriju, uz tendenciju grupiranja rezultata nevoljenog selfa oko nižih vrijednosti, a ohrabrujućeg selfa oko viših vrijednosti. Nezavisno provedeni Kolmogorov-Smirnovljev testovi ukazuju na određena spomenuta odstupanja dobivenih distribucija od normalne krivulje (prema višim ili nižim vrijednostima), ali provjereni zasebni indeksi asimetričnosti i indeksi spljoštenosti nisu veliki i u okvirima su prihvatljivih za provedbu parametrijskih analiza (asimetričnost $<1$, spljoštenost $<3$ ) (Kline, 2005). Nadalje, dobivene korelacije ukazuju kako su ispitivane varijable u značajnim umjerenim odnosima, a jedino korelacije indeksa tjelesne mase i ostalih mjerenih varijabli nisu statistički značajne. Dobivene korelacije kompulzivnog prejedanja i mjerenih varijabli ukazuju da su manje sklone kompulzivnom prejedanju osobe koje bolje reguliraju negativne emocije i koje u manjoj mjeri traže uzbuđenje uslijed negativnog raspoloženja. Osobe koje se lako razočaraju u sebe kao i one koje osjećaju gađenje i mržnju prema sebi iskazuju veći stupanj kompulzivnog prejedanja. S druge strane, 
ohrabrujući self korelira negativno s kompulzivnim prejedanjem i ukazuje da osobe koje sebe ohrabruju i koje su nježne i podržavajuće prema sebi iskazuju manju sklonost kompulzivnom prejedanju.

Osvrt na rezultate na ljestvici prejedanja ukazuje kako se na ukupnom uzorku rezultati kreću od 0 do 46, dok prosječan rezultat sudionica ovog istraživanja iznosi $\mathrm{M}=14,37$ i odgovara kategoriji izostanka poremećaja kompulzivnog prejedanja s obzirom na ukupni rezultat. Specifičnije, $68 \%$ $(\mathrm{N}=207)$ sudionica procjenjuje nisku sklonost kompulzivnom prejedanju, $24 \%$ sudionica $(\mathrm{N}=72)$ pokazuje blago do umjereno kompulzivno prejedanje, dok $8 \%$ sudionica $(\mathrm{N}=23)$ pokazuje ozbiljan poremećaj kompulzivnog prejedanja.

\section{Doprinos osobnih čimbenika u objašnjenju kompulzivnog prejedanja}

Kako bi se provjerilo u kojoj mjeri različiti osobni čimbenici doprinose objašnjenju kompulzivnog prejedanja, provedena je hijerarhijska regresijska analiza (Tablica 2). Provjereni su doprinosi triju skupina prediktora - emocionalne regulacije i kontrole, razine uzbuđenja uslijed negativnog raspoloženja, dimenzija samokritičnosti (neadekvatan i nevoljeni self) i samoohrabrivanja. Temeljem nultih korelacija između kompulzivnog prejedanja i Indeksa tjelesne mase (ITM), ova varijabla je izostavljana iz hijerarhijske regresijske analize. Način uvođenja prediktora u analize omogućava otkriva- nje zasebnih relativnih doprinosa pojedinih skupina osobnih čimbenika u objašnjenju kompulzivnog prejedanja. Slijedi prikaz rezultata hijerarhijske regresijske analize provedene na uzorku od 302 djevojke.

Rezultati provedene hijerarhijske regresijske analize u prvom koraku ukazuju da emocionalna regulacija i kontrola značajno negativno doprinosi objašnjenu varijance kompulzivnog prejedanja $(\beta=-0,45)$. Emocionalnom regulacijom i kontrolom objašnjeno je 20,2 \% ukupne varijance kompulzivnog prejedanja, a rezultati ukazuju da sudionice koje bolje reguliraju i kontroliraju negativne emocije su manje sklone kompulzivnom prejedanju. Drugi blok varijabli činila je razina traženja uzbuđenja uslijed negativnog raspoloženja pri čemu je objašnjeno dodatnih $8 \%\left(\Delta \mathrm{R}^{2}=0,08\right)$ varijance kriterija kompulzivnog prejedanja. Razina traženja uzbuđenja uslijed negativnog raspoloženja značajno pozitivno doprinosi objašnjenju kriterija $(\beta=0,41)$, sudionice koje imaju manju razinu traženja uzbuđenja uslijed negativnog raspoloženja su ujedno i manje sklone kompulzivnom prejedanju. U trećem koraku dodane su dimenzije samokritičnosti (neadekvatan self i nevoljeni self) te samoohrabrivanje koje su značajno povećale proporciju objašnjene varijance kompulzivnog prejedanja za 17,2 $\%\left(\Delta \mathrm{R}^{2}=0,172\right)$. Razina traženja uzbuđenja uslijed negativnog raspoloženja i dalje je ostala značajnim pozitivnim prediktorom kompulzivnog prejedanja $(\beta=0,24)$, uz nevoljeni self $(\beta=0,41)$ koji je također

Tablica 2. Rezultati hijerarhijske regresijske analize s emocionalnom regulacijom i kontrolom, razinom uzbuđenja uslijed negativnog raspoloženja, dimenzijama samokritičnosti (neadekvatni self, nevoljeni self) i samoohrabrivanjem kao prediktorima te kompulzivnim prejedanjem kao kriterijem ( $N=302)$

\begin{tabular}{|c|c|c|c|c|c|c|c|c|c|}
\hline \multirow{4}{*}{ Prediktori } & \multicolumn{9}{|c|}{ KOMPULZIVNO PREJEDANJE } \\
\hline & \multicolumn{3}{|c|}{ I. korak } & \multicolumn{3}{|c|}{ II. korak } & \multicolumn{3}{|c|}{ III. korak } \\
\hline & \multicolumn{3}{|c|}{$\begin{array}{c}\mathrm{R}=0,450 \\
\mathrm{R}^{2}=0,202 \\
\mathrm{~F}(1,300)=76,21, \mathrm{p}<0,01\end{array}$} & \multicolumn{3}{|c|}{$\begin{array}{c}\mathrm{R}=0,532 \\
\mathrm{R}^{2}=0,284 \\
\Delta \mathrm{R}^{2}=0,080 \\
\mathrm{~F}(2,299)=59,26 ; \mathrm{p}<0,01\end{array}$} & \multicolumn{3}{|c|}{$\begin{array}{c}\mathrm{R}=0,675 \\
\mathrm{R}^{2}=0,456 \\
\Delta \mathrm{R}^{2}=0,172 \\
\mathrm{~F}(5,296)=49,63 ; \mathrm{p}<0,01\end{array}$} \\
\hline & $\boldsymbol{\beta}$ & $\mathbf{t}(300)$ & $\mathbf{p}$ & $\boldsymbol{\beta}$ & $t(299)$ & $\mathbf{p}$ & $\beta$ & $\mathrm{t}(298)$ & $\mathbf{p}$ \\
\hline Emocionalna regulacija i kontrola & $-0,45 * *$ & $-8,73$ & $<0,01$ & $-0,16^{*}$ & $-2,26$ & $<0,05$ & 0,04 & 0,61 & $>0,05$ \\
\hline Uzbuđenje uslijed negativnog raspoloženja & & & & $0,41 * *$ & 5,83 & $<0,01$ & $0,24 * *$ & 3,81 & $<0,01$ \\
\hline Neadekvatni self & & & & & & & 0,08 & 1,11 & $>0,05$ \\
\hline Nevoljeni self & & & & & & & $0,41 * *$ & 5,81 & $<0,01$ \\
\hline Samoohrabrujući self & & & & & & & $-0,10$ & $-1,82$ & $>0,05$ \\
\hline
\end{tabular}

Napomena: $\beta=$ vrijednost standardiziranog regresijskog koeficijenta; $\mathrm{t}=$ vrijednost $\mathrm{t}$-testa; $\mathrm{p}=$ razina značajnosti; $\Delta \mathrm{R}^{2}=$ doprinos pojedine grupe prediktora objašnjenoj varijanci; $\mathrm{R}^{2}=$ ukupan doprinos objašnjenoj varijanci; $\mathrm{F}=$ vrijednost ukupnog F-omjera; $* \mathrm{p}<0,05 ; * * \mathrm{p}<0,01$ 
značajno pozitivno doprinio objašnjenju ukupne varijance kriterija. Dobiveni rezultat ukazuje kako su sudionice koje imaju izraženiji nevoljeni self sklonije kompulzivnom prejedanju. Neadekvatan self $(\beta=0,08)$ i samoohrabrujući self $(\beta=0-, 10)$ nisu se pokazali značajnim prediktorima. Treba istaknuti kako je u trećem koraku analize, uvođenjem dimenzija samokritičnosti i samoohrabrivanja, emocionalna regulacija i kontrola $(\beta=0,04)$ prestala biti značajan prediktor kompulzivnog prejedanja. Navedene promjene u veličini, odnosno statističkoj značajnosti pojedinih prediktora upućuju kako su rezultati hijerarhijskih analiza osjetljivi na interkorelacije prediktora (koje su značajne) te upućuju na prisutnost supresorskih efekata. Završnim korakom regresijske hijerarhijske analize sveukupno je objašnjeno znatnih 45,6 \% ukupne varijance kompulzivnog prejedanja, a rezultati ukazuju kako su sudionice s višom razinom uzbuđenja uslijed negativnog raspoloženja te izraženijim nevoljenim selfom sklonije kompulzivnom prejedanju.

\section{RASPRAVA}

Kompulzivno prejedanje se može javiti kao reakcija na negativne životne situacije, emocije i događaje, a zasigurno predstavlja neadekvatan način suočavanja sa svakodnevnim životnim problemima i pritiscima. Budući da istraživanja pokazuju da doživljavanje negativnih emocija i stresa dovodi do povećane želje za hranom i veće sklonosti kompulzivnom prejedanju (Bongers i sur., 2015), te rijetkih istraživanja kompulzivnog prejedanja u Hrvatskoj kao i nejasnih uzročnih čimbenika, cilj ovoga istraživanja bio je ispitati doprinos različitih osobnih čimbenika (razine emocionalne regulacije i kontrole, razine traženja uzbuđenja uslijed negativnog raspoloženja, dimenzija samokritičnosti i samoohrabrivanja te indeksa tjelesne mase) u objašnjenju sklonosti kompulzivnom prejedanju.

S obzirom na mali broj muških sudionika koji su pristupili ispunjavanju online upitnika primijenjenim na internetu, obrade i interpretacije rezultata se odnose samo na ženske sudionice. Na osnovi dobivenih rezultata na ljestvici kompulzivnog prejedanja, utvrđeno je kako se sudionice ovog istraživanja rijetko upuštaju u takve aktivnosti. S obzirom da su u istraživanje uključene većinom studentice koje predstavljaju neklinički uzorak dobiveni rezultat o niskoj sklonosti kompulzivnom prejedanju je očekivan. Međutim, potrebno je istaknuti da je određeni postotak sudionica ovog istraživanja ipak sklon prejedanju (bilo blagom ili ozbiljnom), preciznije $8 \%$ sudionica iskazuje ozbiljnu sklonost kompulzivnom prejedanju, dok $24 \%$ sudionica iskazuje blago do umjereno kompulzivno prejedanje. Dobiveni postoci o zastupljenosti kompulzivnog prejedanja su općenito manji u odnosu na rezultate prijašnjih istraživanja (Hudson i sur., 2007; Kessler i sur., 2013).

S obzirom da zbog unosa velike količine kalorija osobe s poremećajem kompulzivnog prejedanja mogu imati prekomjernu tjelesnu težinu, u ovom istraživanju se kontrolirao i Indeks tjelesne mase kao jedan od mogućih objektivnih pokazatelja poremećaja hranjenja. Iako nije postavljena jednoznačna hipoteza o njegovom doprinosu objašnjenju kompulzivnog prejedanja s obzirom na nekonzistentnost rezultata prijašnjih istraživanja (Mackenzi i Harris; 2015; Bulik i ReichbornKjennerud, 2003; Hudson i sur., 2007), hipoteza o njegovoj značajnoj ulozi nije potvrđena u ovom istraživanju temeljem nultih korelacija s kompulzivnim prejedanjem te isključivanjem iz hijerarhijske regresijske analize. Također, treba istaknuti da su djevojke koje su sudjelovale u istraživanju, prema indeksu tjelesne mase, većinom normalne tjelesne težine. Iako dobivene korelacije u ovom istraživanju upućuju na značajan odnos svih drugih mjerenih osobnih čimbenika (preciznije emocionalne regulacije i kontrole, razine uzbuđenja uslijed negativnog raspoloženja kao i dimenzija samokritičnosti i samoohrabrivanja) i kompulzivnog prejedanja, provjere zasebne uloge pojedinih čimbenika, primjenom hijerarhijske regresijske analize, upućuju na značajne zasebne doprinose samo nekih varijabli. Preciznije nevoljeni self (kao dimenzija samokritičnosti) i razina uzbuđenja uslijed negativnog raspoloženja su, uz kontrolu ostalih varijabli, jedini značajni prediktori te ukazuju da su djevojke s višom razinom uzbuđenja uslijed negativnog raspoloženja te izraženijom ljutnjom i gađenjem prema sebi sklonije kompulzivnom prejedanju. Dobiveni rezultat je u skladu s prijašnjim istraživanja koja su ukazala da je razina uzbuđenja uslijed negativnog raspoloženja značajan prediktor 
objašnjenju kompulzivnog prejedanja (Anestis i sur., 2009; Claes i sur., 2005) te kako se navodi na temelju meta-analize Fischera, Smitha i Cydersa (2008) i najvažniji prediktor kompulzivnog prejedanja. Odnosno, osobe koje imaju tendenciju da na negativno raspoloženje reagiraju impulzivno u povećanom su riziku od kompulzivnog prejedanja, budući da mogu koristiti kompulzivno prejedanje kao strategiju reguliranja negativnih emocija (Fischer i sur., 2008). Drugim riječima, pojedinci se upuštaju u kompulzivno prejedanje kako bi reducirali negativno raspoloženje (Fischer i sur., 2012). Dobivena pozitivna povezanost može se objasniti smanjenom bihevioralnom kontrolom osoba kada su neraspoložene (Fischer i sur., 2007). Sklonost kompulzivnom prejedanju ne samo da kratkoročno reducira negativno raspoloženje, već kratkoročno povećava pozitivno raspoloženje (Smyth i sur., 2007), što može preko sustava nagrađivanja dovesti do začaranog kruga kompulzivnog prejedanja.

Nadalje, značajan doprinos nevoljenog selfa (kao dimenzije samokritičnosti) konzistentan je s rezultatima istraživanja u ovom području koja ukazuju kako destruktivniji oblici samokritičnosti (nevoljeni self) snažnije doprinose kompulzivnom prejedanju za razliku od drugih dimenzija samokritičnosti (neadekvatan self) ili samoohrabrivanja (Duarte i sur., 2014). Kako je jedan od aspekata nevoljenog selfa želja za samoranjavanjem ili/i samoozljeđivanjem, odnosno osobe usred doživljavanja velike emocionalne boli, intenzivnih osjećaja ljutnje i frustracije, mogu doživjeti ogromnu količinu mržnje usmjerene prema sebi s posljedicom misli o ranjavanju i ozljeđivanju sebe, a sve s ciljem smanjenja doživljenih negativnih osjećaja, moguće je da poražavajuće misli dovode posljedično do kompulzivnog prejedanja. Osobe koje teško mogu kontrolirati ljutnju i frustraciju prema sebi i koje pamte svoje neuspjehe i zadržavaju se na njima kao i one koje ponekad žele nauditi sebi te koje su se prestale brinuti o sebi, pokazuju i veći stupanj kompulzivnog prejedanja. Dobiveni nalazi u skladu su s rezultatima prijašnjih istraživanja gdje su kod žena s poremećajem kompulzivnog prejedanja, u odnosu na žene nesklone kompulzivnom prejedanju, pronađene više razine samokritičnosti (Noordenbos i sur., 2014; Feinson i Hornik-Lurie, 2016). Također, u istraživanju Kelly i Cartera
(2013) veći broj ozbiljnih poremećaja hranjenja utvrđen je kod osoba koje iskazuju visoke razine samokritičnosti. Odnosno pojedinci s visokom razinom samokritičnosti postavljaju sebi rigidne $i$ nerealistične standarde, te imaju pogubne sumnje o tome je li ono što čine dovoljno dobro te su i vrlo zabrinuti rade li pogreške, što naposljetku može rezultirati grubim negativnim samoevaluacijama u prijetećim situacijama (Blatt, 2004). Istraživanja uzroka poremećaja hranjenja su ukazala na značajnu ulogu razine samokritičnosti u pokušaju oslobađanja ili bijega od osjećaja manje vrijednosti i neuspjeha (Bardone i sur., 2000; Goss i Allan, 2009; Goss i Gilbert, 2002; Gupta i sur., 2008). A kada postoje oštre i negativne samoevaluacije (npr. nisam dovoljno dobar), kompulzivno prejedanje ima funkciju smirivanja i oslobađanja od bolnih emocija barem na kratko razdoblje (Burns i sur., 2012). Dobiveni rezultati ovog istraživanja se mogu objasniti teorijom izbjegavanja, odnosno osobe sklone kompulzivnom prejedanju često sebe procjenjuju prema visoko postavljenim standardima i nedostižnim idealima, te je moguće da nepodudaranje između onoga kakvom osoba sebe vidi i kakva bi htjela biti, vodi kompulzivnom prejedanju. Samoohrabrivanje nije imalo značajan doprinos u objašnjenju kompulzivnog prejedanja iako se ono promatra kao zaštitni faktor s različitim komponentama kao što su sposobnost podsjećanja sebe na pozitivne stvari, na prošle uspjehe, sposobnost toleriranja osobnog razočaranja i osjećaja ranjivosti. Nadalje, potrebno je istaknuti, na temelju provedene hijerarhijske analize, kako je uvođenjem novih zasebnih koraka u analizi, došlo do određenih promjena u veličini regresijskih koeficijenata. Naime, emocionalna regulacija i kontrola je značajno doprinosila objašnjenju kompulzivnog prejedanja sve do uvođenja dimenzija samokritičnosti i samoohrabrivanja. Dobiveni rezultati ukazuju kako samokritičnost i samoohrabrivanje posreduju u objašnjenju povezanosti između emocionalne regulacije i kontrole i sklonosti kompulzivnom prejedanju.

$\mathrm{Na}$ kraju je potrebno navesti određene nedostatke provedenog istraživanja. Kao prvo, istraživanje je korelacijske prirode te se stoga moraju uzeti u obzir određeni nedostaci kao što je nemogućnost predviđanja uzročno-posljedičnih odnosa među 
varijablama. Sljedeći nedostatak se odnosi na uzorak istraživanja koji je bio prigodan te je prikupljeno dovoljno podataka za obradu podataka jedino za žene. To se može promatrati kao nedostatak istraživanja upravo iz razloga što u današnje vrijeme sve veći broj muškaraca također iskazuje određene poremećaje hranjenja te bi u budućim istraživanjima bilo korisno prikupiti i dostatne podatke za muški uzorak. Ujedno bi i uključivanje kontrolne grupe tj. kliničkog uzorka osoba s poremećajima hranjenja moglo omogućiti jasnije razmatranje etioloških faktora, pogotovo uključivanjem kontrolne grupe sudionika koji bi imali Indeks tjelesne mase iznad 30. Također, rezultati istraživanja temelje se na samoprocjenama sudionica koje mogu biti pod različitim ograničenjima, pristranostima ili nemogućnostima pojedinca da u datom trenutku procijeni sebe i uobičajene obrasce hranjenja. U istraživanju se nije kontrolirala faza menstrualnog ciklusa sudionica, a u nekim istraživanjima (Schoofs i sur., 2011; Klump i sur., 2008) se ukazuje kako statistički značajno doprinosi objašnjenju kompulzivnog prejedanja te se preporuča kao kontrolna varijabla u budućim istraživanjima.

\section{ZAKLJUČAK}

Provedeno istraživanje pruža uvid u ulogu nekih osobnih čimbenika u objašnjenju kompulzivnog prejedanja djevojaka, preciznije negativnu ulogu izražene samokritičnosti (nevoljenog selfa) i uzbuđenja uslijed negativnog raspoloženja te djelomično potvrđuje postavljene hipoteze istraživanja. Odnosno rezultati ukazuju na važnost uloge osjećaja prema sebi i doživljenog uzbuđenja prilikom negativnog raspoloženja kao potencijalnih rizičnih osobnih čimbenika kompulzivnog prejedanja. Utvrđeno je da sve mjerene osobne varijable: emocionalna regulacija i kontrola, uzbuđenje uslijed negativnog raspoloženja, dimenzije samokritičnosti (neadekvatan i nevoljeni self) te samoohrabrivanje objašnjavaju zajedno znatnih $45 \%$ ukupne varijance kompulzivnog prejedanja. Iako u ovom istraživanju samoohrabrivanje nije ostvarilo značajan doprinos u objašnjenju kompulzivnog prejedanja, postoje brojni dokazi kako je razvoj samoohrabrujućeg selfa blagotvoran za mentalno zdravlje kao i za bihevioralnu regulaciju, pa samim time i za manju sklonost kompulzivnom prejedanju (Hofmann i sur., 2011). S obzirom na sve veću prepoznatljivost važnosti samoohrabrivanja, čak i onda kada je osoba samokritična i razočarana sobom, sposobnost samoohrabrivanja trebala bi biti važan terapijski zadatak kod osoba s poremećajima hranjenja (Gilbert, 1997). Stoga navedeni konstrukti zasigurno zahtijevaju detaljnije razmatranje u budućim istraživanjima problema $i$ poremećaja hranjenja. 


\section{LITERATURA}

Ambrosi-Randić, N. (2004): Razvoj poremećaja hranjenja. Jastrebarsko: Naklada Slap.

American Psychiatric Association. (2013): Diagnostic and statistical manual of mental disorders (Peto izdanje). Arlington: American Psychiatric Publishing.

American Psychiatric Association (1994): Diagnostic and statistical manual of mental disorders. 4th ed. Washington, DC.

Anestis, M., Smith, A, Fink, E., i Joiner, T. (2009): Dysregulated eating and distress: Examining the specific role of negative urgency in a clinical sample. Cognitive Therapy and Research. 33(4), 390-397.

Bardone, A., Vohs, K., Abramson, L., Heatherton, T. i Joiner, T. (2000): The consequence of perfectionism, body dissatisfaction and low self-esteem predicts bulimic symptoms: Clinical implications. Behavior Therapy, 31, 265-280.

Baum, A. i Contrada, R. (2011): The handbook of stress science: biology, psychology and health. New York: Springer Publishing Company.

Birchwood, M., Meaden, A., Trower, P., Gilbert, P. i Plaistow, J. (2000): The power and omnipotence of voices: Subordination and entrapment by voices and significant others. Psychological Medicine, 30, 337-344.

Božić, D. (2017): Osobne odrednice kompulzivnog prejedanja. Diplomski rad. Odjel za psihologiju Sveučilišta u Zadru.

Blatt, S. J. (2004): Experiences of Depression: Theoretical, Clinical and Research Perspectives. Washinton, DC: American Psychological Association.

Bongers, P., Van der Akker, K., Havermans, R. i Jansen, A. (2015): Emotional eating and Pavlovian learning: does negative mood facilitate appetitive conditioning?. Appetite, 89, 226-236.

Brockmeyer, T., Skunde, M., Wu, M., Bresslein, E., Rudofsky, G., Herzog, W. i Friedrich, H.C. (2014): Difficulties in emotion regulation across the spectrum of eating disorders. Comprehensive Psychiatry, 55, 565-571.

Bulik, C. M. i Reichborn-Kjennerud, T. (2003): Medical morbidity in binge eating disorder. International Journal of Eating Disorders, 34, 39-46.

Burns, E.E., Fischer, S., Jackson, J.L. i Harding, H.G. (2012): Deficits in emotion regulation mediate the relationship between childhood abuse and later eating disorder symptoms. Child Abuse \& Neglect, 36, 32 - 39.

Carrard, I., Crépin, C., Ceschi, G., Golay, A. i Van der Linden, M. (2012): Relations between pure dietary and dietary-negative affect subtypes and impulsivity and reinforcement sensitivity in binge eating individuals. Eating Behaviors, 13(1), 13-19.

Castilho, P., Pinto-Gouveia, J. i Duarte, J. (2015): Exploring self - criticsm: Confirmatory Factor Analysis of FSCRS in clinical and nonclinical samples. Clinical Psychology and Psychotherapy, 22, $153-164$.

Claes, L., Vandereycken, W. i Vertommen, H. (2005): Impulsivity related traits in eating disorder patients. Personality and Individual Differences, 39, 739-749.

Colditz, G., Willett, W., Rotnitzky, A. i Manson, J. (1995): Weight gain as a risk factor for clinical diabetes mellitus in women. Annals of Internal Medicine, 122 (7), 481-486.

Cole, P.M., Martin, S.E. i Dennis, T.A. (2004): Emotion regulation as a scientific construct: Methodological challenges and directions for child development research. Child Development, 75(2), 317-333.

Cooper, M. J., Wells, A. i Todd, G. (2004): A cognitive model of bulimia nervosa. British Journal of Clinical Psychology, 43(1), 1-16.

Cyders, M.A. i Smith, G.T. (2007): Mood-based rash action and its components: Positive and negative urgency and their relations with other impulsivity-like constructs. Personality and Individual Differences, 43, 839-850.

Del Parigi, A., Chen, K., Salbe, A. D., Reiman, E. M. i Tataranni, P. A. (2003): Are we addicted to food. Obesity Research, 11, 493-495.

Duarte, C., Pinto - Gouveia, J. i Ferreira, C. (2014): Escaping from body image shame and harsh self criticsm: Exploration of underlying mechanisms of binge eating. Eating Behaviors, 15, 638-643. 
Dunkley, D. M., Zuroff, D. C. i Blankstein, K. R. (2003): Selfcritical perfectionism and daily affect: Dispositional and situational influences on stress and coping. Journal of Personality and Social Psychology, 84, $234-252$

Dunkley, D.M. i Grilo, C.M. (2007): Self-criticism, low self-esteem, depressive symptoms, and overevaluation of shape and weight in binge eating disorder patients. Behaviour Research and Therapy, 45, 139-149.

Etu, S. F. i Gray, J. J. (2010): A preliminary investigation of the relationship between induced rumination and state body image dissatisfaction and anxiety. Body Image, 7, 82-85.

Fairburn C.G. (2008): Cognitive behavior therapy and eating disorders. New York: Guilford Press.

Fairburn C.G. (1995): Overcoming Binge Eating. New York: The Guilford Press.

Feinson, M.C. i Hornik-Lurie, T. (2016): „Not good enough“: Exploring self-criticsm`s role as a mediator between childhood emotional abuse \& adult binge eating. Eating Behaviors, 23, 1-6.

Fischer, S., Smith, G.T., Annus, A. i Hendricks, M. (2007): The relationship of neuroticism and urgency to negative consequences of alcohol use in women with bulimic symptoms. Personality and Individual Differences, 43, 1199-1209.

Fischer, S., Smith, G.T. i Cyders M.A. (2008): Another look at impulsivity: A meta-analytic review comparing specific dispositions to rash action in their relationship to bulimic symptoms.Clinical Psychology Review, 28(8), $1413-1425$.

Fischer, S., Settles, R., Collings, B, Gunn, R. i Smith, G.T. (2012): The role of negative urgency in problem drinking and disordered eating: testing a model of comorbidity pathological at risk samples. Psychology of Addictive Behaviors, 26 (1), 112-123.

Fischer, S., Peterson, C.M. i McCarthy, D. (2013): A prospective test of thei Influence of negative urgency and expectancies on binge eating and purging. Psychology of Addictive behaviors, 27 (1), 294-300.

Fox, J. R. i Power, M. J. (2009): Eating disorders and multi-level models of emotion: an integrated model. Clinical Psychology and Psychotherapy, 16(4), 240-267.

Gianini, L.M., White, M.A. i Masheb, R.M. (2013): Eating pathology, emotion regulation, and emotional overeating in obese adults with binge eating disorder. Eating Behavior, 14(3), 309 - 313.

Gilbert, P. (1997): The evolution of social attractiveness and its role in shame, humiliation, guilt and therapy. British Journal of Medical Psychology, 70, 113-147.

Gilbert, P., Clarke, M., Hempel, S., Miles, J. i Irons, C. (2004): Criticizing and reassuring oneself: An exploration of forms, styles and reasons in female students.British Journal of Clinical Psychology, 43, 31-50.

Gilbert, P., Baldwin, M. W., Irons, C., Baccus, J. R. i Palmer, M. (2006): Self-criticism and self-warmth: An imagery study exploring their relation to depression. Journal of Cognitive Psychotherapy: An International Quarter, 20(2), 183-200.

Gilbert, J., Stubbs, R.J., Gale, C., Dunk, L. i Thomson, L. (2014): A qualitative study of understanding and use of „compassion focused coping strategies" in people who suffer from weight difficulties. Journal of Compassionate Health Care, 1-9.

Gilboa-Schechtman, E., Avnon, L., Zubery, E. i Jeczmien, P. (2006): Emotional processing in eating disorders: Specific emotional functioning in eating disorders impairment or general distress related deficiency? Depression and Anxiety, 23, 331-339.

Goldschmidt, A.B., Jones, M., Manwaring, J.L., Luce, K.H., Osborne, M.I., Cunning, D. i Taylor, C.B. (2008): The clinical significance of loss of control over eating in overweight adolescents. International Journal of Eating Disorders, 41, 153-158.

Goldschmidt, A.B., Tanofsky-Kraff, M. i Wilfley, D.E. (2011): A laboratory-based study of mood and binge eating behavior in overweight children. Eating Behaviors, 21, 37-43.

Goldschmidt, A.B., Wall, M.M, Loth, K.A., Bucchianeri, M.M. i Neumark-Sztainer, D. (2014): Overeating and binge eating in emerging adulthood: 10-year stability and risk factors. Developmental Psychology, 52(3), 475-483. 
Goldschmidt, A.B., Loth, K.A., MacLehose, R.F., Pisetsky, E.M. Bergem j.M. i Neumark-Sztanier, D. (2015): Overeating with and without loss of control: Associations with weight status, weight-related characteristics, and psychosocial health. International Journal of Eating Disorders, 48 (8), 1150 - 1157.

Goss, K. i Gilbert, P. (2002): Eating disorders, shame and pride: A cognitive-behavioural functional analysis. In P Gilbert \& J Miles (Eds.), Body shame: Conceptualisation, research and treatment (str. 219-255). New York: Brunner Routledge.

Goss, K. i Allan, S. (2009): Shame, pride and eating disorders. Clinical Psychology and Psychotherapy, 16, 303-316.

Graaf, R., Haro, J.M., Kovess-Masfety, V., O`Neill, S., Posada-Villa, J., Sasu, C., Scott, K., Viana, M.C. i Xavier, M. (2013): The prevalence and correlates of binge eating disorder in the WHO World Mental Health Surveys. Biological Psychiatry, 73 (9), 904-914.

Gross, J. J. (1998): Antecedent and response focused emotion regulation: Divergent consequences for experience, expression, and physiology. Journal of Personality and Social Psychology, 74, 234-237.

Gross, J. J. (2001): Emotion regulation in adulthood: Timing is everything. Current Directions in Psychological Science, 10, 214-219.

Grucza, R.A., Przybeck, T.R. i Cloninger, R. (2007): Prevalence and correlates of binge eating disorder in a community sample. Comprehensive Psychiatry, 48(2), 124-131.

Gupta, S., Rosenthal, M., Mancini, A., Cheavens, J. i Lyinch, T. (2008): Emotion regulation skills mediate the effects of shame on eating disorder symptoms in women. Eating Disorders, 16, 404-417.

Heatherton, T.F. i Baumeister, R.F. (1991): Binge eating as escape from self-awareness. Psychological Bulletin, 110(1), 86-108.

Hilbert, A., Rief, W., Tuschen-Caffier, B., de Zwaan, M. i Czaja, J. (2009): Loss of control eating and psychological maintenance in children: An ecological momentary assessment study. Behaviour Research and Therapy, 47, $26-33$.

Hofmann, S. G., Grosman, P. i Hinton, D.E. (2011): Loving-kindness and compassion meditation: Potential for psychological interventions. Clinical Psychology Review, 31, 1126-1132.

Hood, M. M., Grupski, A. E., Hall, B. J., Ivan, I. i Corsica, J. (2013): Factor structure and predictive utility of the binge eating scale in bariatric surgery candidates. Surgery for Obesity and Related Diseases, 9(6), 942-948.

Hudson, J. I., Hiripi, E., Pope Jr, H. G. i Kessler, R. C. (2007): The Prevalence and Correlates of Eating Disorders in the National Comorbidity Survey Replication. Biological Psychiatry, 61(3), 348-358.

Johnson, C. i Larson, R. (1982): Bulimia: an analysis of moods and behavior. Psychosomatic Medicine, 44, 341-351.

Keel, P. K., Baxter, M. G., Heatherton, T. F. i Joiner Jr, T. E. (2007): A 20-year longitudinal study of body weight, dieting, and eating disorder symptoms. Journal of Abnormal Psychology, 116(2), 422-432

Keel, P. K. i Levitt, P. (2006): Eating disorders. New York: Chelsea House Publisher.

Kelly, A.C. i Carter, J.C. (2013): Why self - critical patients present with more severe eating disorder pathology: The mediation role of shame. British Journal of Clinical Psychology, 52, 148-161.

Kelly, N. R., Bulik, C. i Mazzeo, S. E. (2013): Cognitive and behavioral impulsivity among young women who binge eat. International Journal of Eating Disorders, 46, 127-139.

Kelly-Weeder, S., Jennings, K.M. i Wolfe, B.E. (2012): Gender differences in binge eating and behavioral correlates among college students. Eating and Weight Disorders, 17(3), 200-202.

Kessler, R.C., Berglund, P.A., Chiu, W.T., Deitz, A.C., Hudson, J.I., Shahly, V., Aguilar-Gaxiola, S., Alonso, J., Angermeyer, M.C., Benjet, C., Bruffaerts, R., de Girolamo, G., de Graaf, R., Haro, J.M., Kovess-Masfety, V., O`Neill, S., Posada-Villa, J., Sasu, C., Scott, K., Viana, M.C. i Xavier, M. (2013): The prevalence and correlates of binge eating disorder in the WHO World Mental Health Surveys. Biological Psychiatry, 73 (9), 904-914.

Kline, R.B. (2005): Principles and practice of structural equation modeling. New York: The Guilford Press.

Klump, K.L., Keel, P.K., Culbert, K.M. i Edler, C. (2008): Ovarian hormones and binge eating: exploring associations in community samples. Psychological Medicine, 38, 1749- 1757. 
Kupeli, N., Chilcot, J., Schmidt, U.H., Campbell, I.C. i Troop, N.A. (2012): A confirmatory factor analysis and validation of the Forms of Self-criticism/Self reassurance Scale. British Journal of Clinical Psychology, 51 (1), 12-25.

Lake, A. J., Staiger, P. K. i Glowinski, H. (2000): Effect of Western Culture on Women's Attitudes to Eating and Perceptions of Body Shape. International Journal of Eating Disorder, 27, 83-89.

Lilenfeld, L.R., Wonderlich, S., Riso, L.P., Crosby, R. i Mitchell, J. (2006): Eating disorders and personality: a methodological and empirical review. Clinical Psychology Review, 26, 299-320.

Mackenzie, J. i Harris, L. (2015). Binge eating sympoomatology, BMI, and health. Journal of Eating Disorder,3, 21-22.

Morris, A.S., Silk, J.S., Steinberg, L., Myers, S.S. i Robinson, L.R. (2007): The role of the family context in the development of emotion regulation. Social Development, 16(2), 361-388.

Mouchacca, J., Abbot, G.A. i Ball, K. (2013): Associations between psychological stress, eating, physical activity, sedentary behaviours and body weight among women: a longitudinal study.BMC Public Health, 13, 828 - 839.

Noordenbos, G., Aliakbari, N. i Campbell, R. (2014): The relationship among critical inner voices, low self esteem, and self-criticism in eating disorders. Eating Disorders, 22 (4), 337 - 351.

O'Connor, D.B., Jones, F., Conner, M., McMillan, B. i Ferguson, E. (2008): Effects of daily hassles and eating style on eating behavior. Health Psychology, 27(1), 20-31.

Orzolek-Kronner, C. (2002): The effect of attachment theory in the development of eating disorders: Can symptoms be proximity-seeking? Adolescent Social Work Journal, 19 (6), 421-435.

Pearson, C.M, Combs, J.L, Zapolski, T.C. i Smith, G.T. (2012): A longitudinal transactional risk model for early eating disorder onset. Journal of Abnormal Psychology, 121, 707-718.

Peck, L.D. i Lightsey, O.R.Jr. (2008): The eating disorders continuum, self-esteem, and perfectionism. Journal of Counsueling Development,86, 184-192.

Pokrajac-Bulian, A. (2000): Nezadovoljstvo vlastitim tijelom i teškoće emocionalne prilagodbe kao odrednice nastanka poremećaja hranjenja. Doktorska disertacija. Zagreb: Odsjek za psihologiju Sveučilišta u Zagrebu.

Pokrajac-Bulian, A., Tkalčić, M. i Ambrosi-Randić, N. (2013): Binge eating as a determinant of emotional state in overweight and obese males with cardiovascular disease. Maturitas, 74, 352-356.

Pokrajac-Bulian, A., Tkalčić, M., Kardum, I., Šajina, Š i Kukić, M. (2009): Perfekcionizam, privatna svijest o sebi, negativan afekt i izbjegavanje kao odrednice prejedanja. Društvena istraživanja, 1-2, 111-128.

Polivy J., Coleman J. i Herman C.P. (2005): The Effect of Deprivation on Food Cravings and Eating Behavior in Restrained and Unrestrained Eaters. International Journal of Eating Disorder, 38, 301-309.

Preti, A., Girolamo, G., Vilagut, G., Alonso, J., Graaf, R. i Bruffaerts, R. (2009): The epidemiology of eating disorders in six European countries: results of the ESEMeD-WMH project. Journal of Psychiatric Research, 43, 1125-1132.

Prisco, A.N.C., Araújo, T. M., Almeida, M.M.G. i Santos, K.O.B. (2013): Prevalência de transtornos alimentares em trabalhadores urbanos de município do Nordeste do Brasil. Ciência \& Saúde Coletiva, 18(4), 1109-1118.

Schoofs, N., Chen, F., Bräunig, P. i Stamm, T. (2011): Binge eating disorder and menstrual cycle in unmedicated women with bipolar disorder. Journal of Affective Disorder, 129, 75-78.

Shahar, B., Szepsenwol O., Zilcha-Mano, S., Haim, N., Zamir, O., Levi-Yeshivi, S. i Levit-Binnun, N. (2015): A waitlist randomized controlled trial of loving-kindness meditation programme for self-criticism. Clinical Psychology and Psychotherapy, 22 (4), 346-356.

Shomaker, L.B., Tanofsky-Kraff, M., Elliott, C., Wolkoff, L.E., Columbo, K.M., Ranzenhofer, L.M. i Yanovski, J.A. (2010): Salience of loss of control for pediatric binge episodes: does size really matter? International Journal of Eating Disorders, 43, 707-716.

Smith, J.P. i Tran, G.Q. (2007): Does negative affect increase change readiness among college hazardous drinkers? Addictive Behaviors, 32, 2281-2285. 
Smyth, J.M., Wonderlich, S.A., Heron, K.E., Sliwinski, M. J., Crosby, R.D., Mitchell, J.E. i Engel, S.G. (2007): Daily and momentary mood and stress are associated with binge eating and vomitnig in Bulimia nervosa patients in the natural environment. Journal of Consulting and Clinical Psychology, 75, 629-638.

Soares, M.J., Macedo, A., Bos, S.C., Marques, M., Maia, B., Pereira, A.T., Gomes, A., Valente, J., Pato, M. i Azevedo, M.H. (2009): Perfectionism and Eating Attitudes in Portuguese Students: A Longitudinal Study. European Eating Disorder Review, 17, 390-398.

Spoor, S.T., Bekker, M.H., van Strien, T. i van Heck, G.L. (2007): Relations between negative affect, coping, and emotional eating. Appetite, 48(3), 368-376.

Stice, E. i Whitenton, K. (2002): Risk factors for body dissatisfaction in adolescent girls: a longitudinal investigation. Developmental Psychology, 38, 669-678.

Striegel-Moore, R. H., Silberstein, L. R., Grunberg, N. E. i Rodin, J. (1990): Competing on all fronts: Achievement orientation and disordered eating. Sex Roles, 23(11), 697-702.

Striegel-Moore, R.H. i Franko, D.L. (2003): Epidemiology of binge eating disorder. International Journal of Eating Disorders, 34, 19-29.

Strother, E., Lemberg, R., Chariese, S., Turberville, S. i Turberville, D. (2012): Eating Disorders in Men: Underdiagnosed, Undertreated, and Misunderstood. Eating Disorders: The Journal of Treatment \& Prevention, 20(5), 346-355.

Svaldi, J., Tuschen-Caffier, B., Peyk, P. i Blechert, J. (2010): Information processing of food pictures in binge eating disorder. Appetite, 55(3), 685-694.

Takšić, V. (2003). Skala emocionalne regulacije i kontrole (ERIK): Provjera faktorske strukture. Psihologijske teme, $12,43-53$.

Vancampfort, D., Correll, C. U., Probst, M., Sienaert, P., Wyckaert, S. i De Herdt, A. (2013): A review of physical activity correlates in patients with bipolar disorder. Journal of Affective Disorders,145,285-291.

Whiteside, S.P. i Lynam, D.R. (2009): Understanding the role of impulsivity and externalizing psychopathology in alcohol abuse: Application of the UPPS Impulsive Behavior Scale. Personality Disorders: Theory, Research, and Treatment, 1, 69-79.

\section{THE ROLE OF PERSONAL FACTORS IN EXPLAINING BINGE EATING}

\footnotetext{
Abstract: A common characteristic of different forms of eating disorders is the excessive influence of body image and weight in an individual's self-evaluation, as well as irregular or chaotic patterns of food intake. Binge eating is a separate eating disorder that involves the ingestion of an unusually large amount of food in a short period, followed by an intense sense of loss of control. Past research has shown the importance of personal factors in explaining binge eating. The aim of this study was to examine the role of emotional regulation and control, the level of negative urgency, self-criticisms and self-reassurance, and body mass index in explaining binge eating. The research was conducted on a sample of 302 girls, the average age was 22 years (SD=2.70), and the data were collected using an on-line questionnaire. Hierarchical regression analysis was used to determine separate contributions of individual groups of personal factors explaining binge eating in girls. The level of negative urgency and hated self, as a dimension of self-criticism, were significant individual factors behind binge eating. In conclusion, the results indicate that girls with a higher level of negative urgency and higher level of hated self are more likely to binge eat, and personal factors selected in this study explained $45.6 \%$ of binge eating variance.
}

Keywords: binge eating, emotional regulation, negative urgency, self-criticism, self-reassurance, body mass index 